\title{
Dictynna
}

Dictynna

Revue de poétique latine

$6 \mid 2009$

Varia

\section{Ovid's Sappho and Roman Women Love Poets}

\author{
Judith P. Hallett
}

\section{(2) OpenEdition}

\section{Journals}

Electronic version

URL: http://journals.openedition.org/dictynna/269

DOI: 10.4000/dictynna.269

ISSN: 1765-3142

\section{Electronic reference}

Judith P. Hallett, «Ovid's Sappho and Roman Women Love Poets », Dictynna [Online], 6 | 2009, Online since 29 November 2010, connection on 10 December 2020. URL : http://journals.openedition.org/ dictynna/269; DOI : https://doi.org/10.4000/dictynna.269

This text was automatically generated on 10 December 2020 .

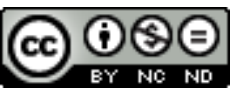

Les contenus des la revue Dictynna sont mis à disposition selon les termes de la Licence Creative Commons Attribution - Pas d'Utilisation Commerciale - Pas de Modification 4.0 International. 


\title{
Ovid's Sappho and Roman Women Love Poets
}

\author{
Judith P. Hallett
}

1 Ovid's erotic poetry portrays love as an enterprise in which women and men engage together, playfully and creatively. His writings acknowledge that the production and consumption of poetry about love are enterprises in which women engage too. Most notably, he represents Heroides 15 as a letter in elegiac verse from the celebrated sixth century BCE female poet Sappho to her young male lover Phaon; at Amores 2.8. 26 and 34 , when adopting the role of poet-speaker, he also announces his plans to write in the persona of Sappho. He makes complimentary remarks about Sappho and her poetry elsewhere in his works as well : at ArsAmatoria 3.331, where, assuming the persona of praeceptor amoris, he proffers erotic advice to his female readers; and at Tristia 2. 365-366, where, speaking in his own person about his poetry after his banishment to the Black Sea, he defends his choice of erotic subject matter to Augustus.

2 What is more, at lines 59-60 of his autobiographical Tristia 4.10 Ovid confesses that in his Amores he referred to his beloved by a name, "not her own" (nomine non vero) but that of another, earlier, Greek female poet, Corinna. In Tristia 3.7, another selfrevelatory and self-exculpatory poem from exile, Ovid addresses a young female literary protégée whom he calls Perilla ; after invoking Sappho as a literary model, he warns Perilla in 29-30 against writing verses that teach others how to love, although not against composing erotic poetry itself. In a more oblique fashion, he pointedly characterizes various female figures in his epic Metamorphoses as skillful erotic communicators, chief among them Thisbe in Book 4. While he does not specifically portray Thisbe as composing poetry, or even as engaged in the creation of narrative art through weaving like Arachne or Philomela, the eloquent words he places in Thisbe's mouth are, of course, in dactylic hexameter. ${ }^{1}$

3 Consequently, it is both striking and surprising that Ovid's discussions of Roman love poetry, whether voiced as poet-speaker, as praeceptor amoris or in propria persona, do not evidently acknowledge the work of any Roman women love poets, especially in view of the prominence that he accords Sappho not only in his erotic elegiac works but also his 
poems from exile. My discussion attempts to account for this puzzling feature of his writing. I will argue that Ovid does make such acknowledgments, but in a subtle and indirect way, through allusions, at times to speak critically of Roman women's love poetry. I will also maintain that Ovid diminishes the contributions of Roman women love poets precisely because of the prominence accorded Sappho in his work, in order to identify himself with Sappho, as her true Roman counterpart.

\section{Sappho and Roman Women Love Poets in Tristia 2}

In Tristia 2, a lengthy plea written in his own person to Augustus from exile, Ovid refers to numerous writers of love poetry so as to justify his own literary practices. At lines $361 \mathrm{ff}$., defending the content of what he himself has written, he cites a roster of first Greek and then Roman predecessors who celebrated erotic passion without suffering adverse consequences. Significantly, the second in his roster of Greek love poets is Sappho, about whom he states at 365-366, Lesbia quid docuit Sappho, nisi amarepuellas? / tuta tamen Sappho, "what did Sappho of Lesbos teach, other than girls how to love - or how to love girls - yet Sappho was safe."

Before we turn to Ovid's comparable roster of Roman poets who wrote on erotic topics with impunity, we should accord attention to his use of the adjective "Lesbia" in the context of invoking Sappho. By the final decades of the first century BCE, well before Ovid left Rome for Tomis, this word was closely associated with the love poetry, and the female love interest, of his illustrious and admired predecessor Catullus. ${ }^{2}$ The ambiguity of the phrase amare puellas is noteworthy as well. It testifies to the tradition that Sappho not only instructed young women in the arts of loving, but also instructed her poetic audience about how to love young women. Yet Ovid does not say outright that those loved by the young women depicted in Sappho's poetry, or that those depicted as loving them, were other women, among them Sappho herself. This proves to be a significant ambiguity in view of how he has characterized Sappho elsewhere, a detail to which we will return later.

Ovid's roster, at Tristia 2. 421 ff., of Roman poets who wrote on erotic topics, immediately contrasts with his preceding list of Greek love poets, since it contains no female Roman counterpart to Sappho. Indeed, at first glance it seems to contain no references to any woman poet. But close inspection suggests that Ovid may well be alluding to several women poets without mentioning them directly. Most important, in lines 427-430 he states about Catullus, the third poet on his list, sic sua lascivo cantata estsaepe Catullo/femina, cui falsum Lesbia nomen erat. Nec contentus ea, multos vulgavit amores, in quibus ipse suum fassus adulterium est, "often in this way his woman, to whom the false name Lesbia was assigned, was celebrated in song by sexually playful Catullus. And not satisfied with her he broadcast many love affairs (or widely circulated many love poems), in which he himself admitted to his own adultery." 3

While Ovid does not explain Catullus' choice of "false name" for his "woman" here, Catullus' decision to represent his beloved by the pseudonym Lesbia clearly honored Sappho of Lesbos as a poet. In addition to adopting Sappho's distinctive meter in 11 and 51, translating Sappho L-P 31 in 51, and evoking her words in 62, Catullus compliments Caecilius' female beloved with the phrase Sapphica puella/Musa doctior at 35.15-16. ${ }^{4}$ Consequently, by mentioning the actual name that Catullus used for his beloved, Ovid 
highlights Catullus' decision to pay literary homage to Sappho, homage Ovid himself awards to Sappho by including her in his roster of Greek poets.

The second century CE author Apuleius casts further light on Catullus' choice of the pseudonym Lesbia at Apologia 10. There he notes : Eadem igitur opera accusent C. Catullum quod Lesbiam pro Clodia nominarit, et Ticidam similiter quod quae Metella erat Perillamscripserit, "For that reason therefore let [those who criticize the use of pseudonyms] accuse Catullus because he supposedly used the name Lesbia for Clodia, and likewise Ticidas because he supposedly wrote of a woman as Perilla who was actually called Metella." On the basis of this statement, as well as of other evidence from Catullus' own poetry and elsewhere, the woman he calls Lesbia is usually identified as Clodia Metelli : a sister of the demagogue Publius Clodius Pulcher, and the wife of Q. Caecilius Metellus Celer, consul in 60 BCE. ${ }^{5}$ By referring to Clodia Metelli as "Lesbia", moreover, Catullus may have acknowledged that Clodia Metelli was herself a poet, a counterpart as well as a reader of the Greek Sappho. Ovid may have highlighted Catullus' decision to identify his beloved by the pseudonym "Lesbia" for the same reason.

9 After all, Catullus represents Lesbia as speaking, and speaking "poetically", in various poems. In poem 36 , for example, he portrays her as criticizing his own poetry; in poem 70 he represents her as recalling earlier Greek Hellenistic poetry with her professions of love to him. ${ }^{6}$ Furthermore, when attempting to discredit Clodia Metelli in chapter 64 of his Pro Caelio, a courtroom speech on behalf of a privileged young man who had once been Clodia's lover, Catullus' contemporary Cicero refers to her with the noun poetria: [velut haec tota fabella] veteris et plurimarum fabularum poetriae., "[this entire little fictional story] by a female poet, of longstanding and a very great number of narrative plots" Other authors, including - as we will see - Ovid himself, use this same noun, of Greek origin and signifying "female poet", to refer to Sappho.

10 To be sure, Cicero utters these words sarcastically, to ridicule Clodia's scheming and plotting. But Cicero's sarcastic tone does not rule out the possibility that Clodia actually wrote poetry. Indeed, his statement is more pointed if she was in fact a poet, a writer of performed words. By the same token, in chapter 116 of his Pro Sestio, Cicero says that Clodia's brother Clodius omnia sororis embolia novit, "knows all of his sister's ballet interludes." Here again Cicero employs a Greek word - embolia - to describe Clodia's literary activities. While he may use this exotic term as a euphemism for her sexual activities, he may well indicate, at the same time, that she composed "dance performances." 7

11 Second, at Tristia 2.437-438, a few lines after his remarks on Catullus, Ovid adduces, as both precedent and justification for his erotic poetic endeavors, a woman who wrote under a pseudonym, et quorum libris modo dissimulata Perillae/nomine, nunc legitur dictaMetella suo, "and in whose books Metella, recently disguised under the name of Perilla, now is read under her actual name." This Metella appears to have been [Caecilia] Metella, a daughter of Clodia Metelli, the woman whom Catullus called Lesbia in his poetry. As we have seen as well, Apuleius identifies Perilla as the pseudonym for Metella that Ticidas used. ${ }^{8}$

12 Significantly, Ovid mentions Ticidas as a reputable forerunner in the realm of erotic poetry a few lines earlier, at $433-434$ of this same passage from Tristia 2 . There he describes Ticidas as using explicit sexual language : quid referam Ticidae, quid Memmi carmen, apud quos/rebus adest nomen nominibusque pudor?, "what am I to say about the 
poetry of Ticidas or of Memmius, in whose writings there is an explicit naming of things, and shame attached to the names." Admittedly, Ovid says nothing here about how or what Metella wrote, or that she was also evidently written about in the poetry of Ticidas. It is possible to construe what Ovid says about Perilla - that "until recently" Perilla was a name disguising Metella - primarily as testimony that only readers since Ticidas' day, such as Ovid himself, been able to learn the actual identity of Ticidas' celebrated inamorata, and that Ticidas, unlike Ovid himself, wrote about an actual woman. But Ovid's reference to Metella may still be interpreted as evoking a poetic precedessor who is "read", another Roman female counterpart to Sappho.

Finally, at lines 440-441 of this passage, Ovid mentions the sexually provocative poems of one Servius: nec minus Hortensi, nec sunt minus improbi Servi carmina? quis dubitet nomina tanta sequi ?, "No less improper are the verses of Hortensius, or those of Servius. Who would hesitate to follow such great names ?" Here Ovid refers to Servius Sulpicius Rufus, an illustrious political leader and jurist who died in 43 BCE. Many scholars view this Servius as the father of the Augustan female poet Sulpicia. ${ }^{9}$

Eleven "Sulpicia elegies" - 8 through 18 in the third book of poems by Tibullus portray her as engaging in a mutually gratifying, illicit love affair with a young man she calls by the pseudonym Cerinthus. These elegies apparently owe their initial publication to the literary patronage of Sulpicia's maternal uncle, Marcus Valerius Messalla Corvinus. A distinguished general, statesman and longtime supporter of Augustus, Messalla is celebrated for championing the literary efforts of Tibullus, and of Ovid himself. ${ }^{10}$

In Amores 3.9, Ovid mourns the death of the youthful Tibullus, an event that can be dated to $19 \mathrm{BCE}$, the same year in which Vergil died, quoting from and rewriting Tibullus' own verses in 1.1 and $1.3 .^{11} \mathrm{He}$ invokes Tibullus as a role model at Tristia 2. 447-464, summarizing the contents of Tibullus' love poetry. But Ovid makes no direct reference in Tristia 2, or anywhere else in his verses, to the poetry of Sulpicia herself.

\section{Addressing Perilla, and invoking Sappho, in Tristia 3.7}

We should pay careful attention to Ovid's indirect way of referring to these Roman women who wrote, or at least appear to have written, love poetry - his mention of Sulpicia's father but not Sulpicia herself; his oblique mode of acknowledging that Metella wrote verse of an erotic nature ; his reference to the pseudonym, paying tribute to the poet Sappho, that Catullus employed for his beloved - when legitimating his love poetry to Augustus in Tristia 2. It sharply contrasts with his direct invocation of Sappho, and the details that he provides about her, a few lines earlier. But another poem, also written after Ovid's exile in $8 \mathrm{CE}$ - Tristia 3.7 - merits note in helping to explain his apparent strategy of downplaying these women as literary predecessors and justifications.

17 Here, writing in propria persona as he does in Tristia 2, Ovid offers literary advice to a young woman poet, whom he also calls Perilla, presumably in homage to the pseudonym used by her predecessor Metella. Ovid asks her if "you are still committed to our common pursuit, and compose learned poetry, though not in your father's way" (11-12 studiiscommunibus ecquid inhaeres/doctaque non patrio carmina more canis); he characterizes her talent as a rare dowry (14 [natura] raras dotes ingeniumque dedit); he takes credit for being her first instructor, "as a father to his daughter, guide and 
comrade" (18 utque pater natae duxque comesquefui). Owing to this reference, and to Ovid's statement that she will greet his letter "while seated with her sweet mother" (3 dulci cum matre sedentem), she is thought by some to be Ovid's stepdaughter. ${ }^{12}$

More significantly, and as noted earlier, in lines 19-20, Ovid tells Perilla that if the same ignes, "fires" "remain in your breast," only the work of the Lesbian bard, Sappho, will surpass yours", sola tuum vates Lesbia vincet opus. Since Sappho wrote love poetry, and since Ovid also refers to the passionate love poems of the Augustan Propertius with the word ignes at Tristia 4.10.45, he may be characterizing Perilla's earlier poems as also erotic in nature. Yet even though Ovid worries that his departure and banishment have caused her to neglect her poetry writing, he vehemently insists that Perilla not follow his example, contrasting her "father's way" with her own "virtuous ways" (13 pudicos mores). He concludes Tristia 3.7 by reminding her of the immortality available to poets, saying that he will be read as long as Rome rules the world. But, in reassuring Perilla about her literary potential, he urges that "no woman or man learn from your writings how to love" (30 neve vir a scriptis discat amaretuis), in the way that they have from his own poetry, and - as he specifies in Tristia 2 - from that of Sappho.

Ovid's admonishing words to his addressee here, a contemporary Roman female poet likely to have written about love, and at risk of adopting an amatory instructional role like the one which he himself assumes in the Ars Amatoria, is understandable in light of his banishment, and of the role possibly played by that poem in his punishment. At Tristia 2.207, he attributes his exile to a "mistake and a poem" (carmen et error). To be sure, he does not identify this poem by name. Yet when addressing Augustus later in the poem, at Tristia 2. 239 ff., he specifically defends the Ars as containing "nothing that allows a charge of misbehavior" (nullum crimen). ${ }^{13}$

\section{Alluding to Sulpicia in Amores 3.14}

Ovid, however, seems to voice criticisms of love poetry by another Roman woman well before both his banishment and even the Ars itself. For he evidently wrote Amores 3.14 soon after the passage, in 18 BCE, of Augustus' "moral legislation", which increased the penalties for extra-marital sexual activity by and with married and marriageable Roman women..$^{14}$ This poem features a first-person male speaker who faults an unnamed female addressee for discussing her sexual feelings and misbehavior in a frank and forthright manner. In it Ovid employs language and themes that figure prominently in Sulpicia's poetry. The affinities with Sulpicia's poems, and the context in which these affinities occur, indeed suggest that he is here obliquely critiquing Sulpicia's outspoken mode of celebrating her illicit love affair, and rebuking her in the persona of an emotionally wounded lover.

21 For example, Amores 3.14 employs four forms of the verb peccare, "to commit a moral transgression, misbehave sexually," within its first eleven lines. Here its speaker agrees to endure the sexual misbehavior of his female addressee, but pleads with her to deny her misbehavior in public. Sulpicia uses this same verb - with peccasse iuvat, "it delights me to have already misbehaved sexually" - at [Tibullus] 3.13.9. She does so after enjoining her readers without love affairs of their own to share her experiences vicariously, while proclaiming to the public that she and her lover have physically consummated their passion. 

woman famosa, "subject of ill rumors", in line 6, the speaker of Amores 3.14 begs his addressee to spare her fama, "what is rumored, reputation", in line 36. He then notes in line 17-18 and 21-22 that while there is no need for pudor," shame", during private lovemaking, pudor should be displayed before others. He also tells her in line 27 to put on a modest facial expression, vultus. Sulpicia uses the word fama twice in [Tibullus] 3.13 , along with pudor and vultus as well : first to assert that the fama, "rumor", that she had covered up her affair would cause her more shame, pudor, than the rumor that she had disclosed it; then to state that she will not put a respectable face, vultus, on her conduct for the sake of fama.

In Amores 3.14 Ovid also repeatedly refers to verba, words, of his female addressee. He mentions her voces, phrases, in line 25 too. It is, in fact, Ovid's emphasis on the language of this woman, and its celebration of her misbehavior, that suggests that his poet-speaker is himself addressing a female poet. And it is the intertextualities, both verbal and thematic similarities, between this poem and the Sulpicia elegies, that render her the most likely candidate for this role. Another apparent allusion to Sulpicia's work in Amores 3.14 is the reference to tabellae, writing tablets, in line 11; echoes of Catullus' poems 51 and 85 in lines 36-40 warrant attention as well. Sulpicia speaks of her unwillingness to entrust the details of her love affair to sealed tablets, signatis tabellis, at 3.13.7, and frequently evokes Catullus' verses. ${ }^{15}$ To be sure, Ovid's dramatic scenario in this poem, as so often in the Amores, involves a substantial amount of fictionalizing, far more than we encounter in his autobiographical poems from exile. But even though Ovid may distance himself from his poet-speaker, his critique of Sulpicia's frankness about her sexual misconduct in her poetic self-portrayal is strong and significant.

\section{Alluding to Sulpicia and identifying with Sappho in the Ars Amatoria}

Ovid continues to evoke Sulpicia, when adopting the voice of an erotic instructor, in Ars Amatoria Book 3, which predates, and may well have provoked, his banishment. And to much the same effect. When advising his female audience about how, and how not, to adorn themselves in lines 29-30, Ovid calls to mind the description of Sulpicia's jewelry at Tibullus 3.8.19-20. Although Sulpicia there receives praise for wearing "whatever gems the dark man of India, near the waters of the dawn, gathers from the shore of the Red Sea" (quascumque niger rubro de litore gemmas/proximus Eois colligit Indus aquis), Ovid here tells his women readers not to "weigh down your ears with expensive stones, which the differently hued man of India gathers in the green water"(non caris aures onerate lapillis,/quos legit in virididecolor Indus aqua). His choice of words, especially Indus and aqua, suggests that he is not merely echoing but also taking issue with what Sulpicia's poetry represents as a key component of her physical appeal.

No Roman women appear in Ovid's roster, at Ars Amatoria $3.329 \mathrm{ff}$, of the poets that he would have his female audience read to enhance their erotic appeal. As observed earlier, Sappho is among the five Greek poets on this list, described with the words quid enim lascivius illa, "what is more sexually playful than she?" But he only mentions the love poets Propertius, Gallus, and Tibullus, and the epic poets Varro of Atax and Vergil as recommended Latin authors. Furthermore, at lines 339-348, Ovid expresses the hope 
that his own name will be added to theirs, owing to the erotic value of his Ars Amatoria, Amores and Heroides, letters in elegiac verse from legendary women to their male lovers.

We will return to the implications of Ovid's self-promotional statement here, to consider how it may explain why a woman appears in his list of Greek, but not Roman, poets recommended to his female readers here. First, however, we should consider the context in which he offers these reading recommendations, immediately after his advice, at lines $312 \mathrm{ff}$., that women learn to sing and accompany themselves on musical instruments. Here Ovid insists that his female readers merely repeat words they have "heard in marble theaters, and songs to Egyptian melodies," and says nothing about composing words of their own. Since he praises the poetry of Sappho, and later reveals - in Tristia 3.7 - that he himself has taught poetry writing to the young woman he calls Perilla, it is noteworthy that he does not raise this as a possibility.

It also merits notice that Ovid returns to the topic of poets at lines $403 \mathrm{ff}$. of Ars Amatoria 3, after he has counseled his female readers about dancing, dice-playing board games, and places in Rome to meet men. Here, when discussing the desirability of being known, he claims that fama, "being known", "renown", is all that poets seek. This discussion eventually leads to advice, in lines $468 \mathrm{ff}$., on how women should write to their lovers on wooden tablets, tabellis. As we have observed, in Tibullus 3.13, Sulpicia twice employs the word fama while emphasizing her own erotic communications on such tablets, and while voicing the hope that her love affair will become known through her poetry, and shared vicariously by her loveless readers.

Ovid may, therefore, also be alluding to Sulpicia's poetry in lines $479 \mathrm{ff}$., where he advises women on what words and sentiments to employ when communicating with their lovers on tablets. In 475-476 he urges a female addressee not to promise (promitte) yourself as an easy conquest, nor to deny what you lover asks ; in 479-490 he tells her to use ordinary, accessible language. He apparently approves of the phrase, lux mea, "light of my life," which is found twice in the Sulpicia elegies, at [Tibullus] 3.9.15 and 3.18.1. At least he wonders, in lines 523-524, if a glum, sexually unresponsive figure of Greek myth, Tecmessa, would have called her husband Ajax lux mea, or used "words which are in the habit of pleasing a lover". ${ }^{16}$

Nonetheless, with these remarks Ovid's praeceptoramoris here seems to criticize Sulpicia's words and sentiments. For Sulpicia not only promises her lover shared physical joys in 3.9 and 11, but also characterizes them at 3.13.5 as what the goddess Venus has made and fulfilled (exsolvit promissa Venus). If Ovid is again obliquely faulting Sulpicia and her poetry, her absence from his list of recommended readings becomes more comprehensible.

Why, though, does Ovid, when adopting the role of love-teacher in the Ars, extol his own writings, the Heroides among them, rather than list a Roman woman poet comparable to Sappho as worthwhile reading for women eager to enhance their amatory appeal ? His words elsewhere in this poem may furnish a clue. While providing advice about communicating on wooden tablets, Ovid recommends that women disguise the identities of illicit lovers by writing in deceptive ways. One tactic that he suggests, in lines 497-498, is "when you write, let your male lover always be described as a woman, and let who was he become she in your messages" (femina dicatur scribenti semper amator:/illa sit in vestris, qui fuit ille, notis). This idea of representing, in writing, a man as a woman warrants emphasis in view of how Ovid portrays Sappho in both Tristia 2 and in Heroides 15, a letter from Sappho to her younger male lover Phaon. It is also of 
a piece with the ambiguities in his representation of Sappho as a lover and love instructor. ${ }^{17}$

31 For, as we have seen, when writing in propria persona at Tristia 2.365-366, Ovid portrays Sappho as teaching girls how to love, or teaching how to love girls, without indicating that Sappho and her poetry portray love among women. At Heroides15.15-20, adopting Sappho's own voice, he has Sappho enumerate various women who no longer hold any appeal for her, concluding with "another hundred whom I have loved without the charge of wrongdoing" (sine crimine)." But this Sappho does not elaborate on the nature of this love. She merely says that Phaon alone now possesses multarum quod fuit: "what was of many women", or "what was for many women". In other words, Ovid downplays and refashions the tradition that Sappho instructed women how to love one another, representing her in this poem primarily as an advocate of women's love by and for men.

What is more, if - according to Ovid - a male lover can and should be fictionally represented as a woman, why not Ovid himself? His advice that women desirous of deceiving represent a male lover as a female casts further light on what he has Sappho declare at Heroides 15.79-80: molle meum levibusque cor est violabile telis,/et semper causa est, cur ego semper amem, "my heart is soft, and damageable by light weapons, and there is always a reason why I always love." As scholars have noted, these lines recall the earlier Amores 2.4,10, where the poet-speaker proclaims : centum sunt causae cur semper amem, "there are a hundred reasons why I always love." ${ }^{18}$ What is more, they are themselves recalled in lines 65-68 of Ovid's autobiographical Tristia 4.10, where he says of himself : molle Cupidineis nec inexpugnabile telis/cor mihi, quodque levis causa moveret, erat, "my heart was soft and not unassailable by Cupid's weapons, the sort of thing which a slight impulse would move."

Consequently, Ovid represents Sappho as he had represented his fictionalized poetic self in the Amores, and as he would later represent himself when acquainting his future readership with "the facts" of his life. Other details in Heroides 15 similarly allow the inference that he is portraying Sappho as his own, present-day, Roman female alter ego. Among them are the echoes of earlier Latin poetry, particularly that of Catullus, in Sappho's words, and the use of his own, signature, elegiac meter for Sappho's words. ${ }^{19}$ Expressing, in Ars Amatoria 3, a hope that the Heroides - including his own fictional letter in the persona of Sappho - will eventually rank along with works by the dead Latin poets recommended to his female readers may be Ovid's indirect way of recommending that women read him, and regard him, as a Roman female love poet.

Heroides 15. 79-80, and the descriptions of Ovid - as poet-speaker in the Amores, and as self-revelatory autobiographer - that they resemble, underscore Sappho's, and Ovid's, erotic vulnerability. Like his words to the young female poet Perilla in Tristia 3.7, these passages appear to critique his own preoccupation with the topic of love, and his portrayal of himself as a vulnerable lover and opinionated amatory expert. They may also explain, if not excuse, why he does not have more to say, at least directly, about love poetry by Roman women. 


\section{BIBLIOGRAPHY}

Glare, P. G.W. 1982 ed., Oxford Latin Dictionary (=OLD) Oxford : Clarendon Press.

Gibson, R.K. 2003 ed., Ovid Ars Amatoria Book 3. Cambridge : Cambridge University Press.

Greene, E. 1996. ed., Re-reading Sappho: Reception and Transmission. Berkeley and Los Angeles : University of California Press.

Gordon, P. 1996. “The Lover's Voice in Heroides 15 : Or, Why is Sappho A Man ?” In J.P. Hallett and M. Skinner eds., Roman Sexualities. Princeton : Princeton University Press : 274-290.

Hallett, J.P. 2005. “Catullan Voices in Heroides 15 : How Sappho Became a Man.” In Dictynna, online publication.

2006. "Catullus and Horace on Roman Woman Poets." Antichthon 40 : 65-88.

2008. "Absent Roman Fathers in the Writings of Their Daughters." In S.R. Huebner and D.M. Ratzan, eds. Growing Up Fatherless in Antiquity. Cambridge : Cambridge University Press : 175-191. 2009a. "Sulpicia and her Resistant Intertextuality", In Écho 8, Université de Lausanne : Jeux de voix, Énonciation, intertextualité et intentionnalité dans la littérature antique : 141-155.

2009b. “Corpus erat : Sulpicia's Elegiac Text and Body in Ovid's Pygmalion Narrative (Met. 10. 238-297)." In T. Foegen and M. Lee, eds.. Bodies and Boundaries in Greco-Roman Antiquity. Berlin : DeGruyter : 111-124.

2009c. "Ovid's Thisbe and a Roman Woman Love Poet". In Approaches toTeaching World Literature. Teaching Ovid and Ovidianism, B.W. Boyd and C. Fox, eds., Modern Language Association.

Hejduk, J.D. 2008. Clodia. A Sourcebook. Norman : University of Oklahoma Press.

Hemelrijk, E.A. 1999. Matrona Docta: Educated Women in the Roman Elite from Cornelia to Julia Domna. New York and London : Routledge.

Hollis, A. S. 1977 ed., Ovid, Ars Amatoria Book I. Oxford : Clarendon Press.

Keith, A. 1997. "Tandem Venit Amor : A Roman Woman Speaks of Love." In Hallett and Skinner, eds. Roman Sexualities. Princeton : Princeton University Press : 295-210.

Knox, P.R. ed. 1995. Ovid Heroides: Select Epistles. Cambridge : Cambridge University Press.

Pelling, C.B.R. 1996. "Valerius Messalla Corvinus, Marcus." In S. Hornblower and A. Spawforth, eds., The Oxford Classical Dictionary, Oxford : Oxford University Press.

Sharrock, A. 1994. Seduction and Repetition in Ovid's Ars Amatoria 2. Oxford University Press.

2002. “An A-musing Tale : Gender, Genre and Ovid's Battles with Inspiration in the Metamorphoses." In E. Spentzou and D.P. Fowler, eds. Cultivating the Muse: Power, Desire, andInspiration in the Ancient World. Oxford : Oxford University Press.

Skoie, M. 2002. Reading Sulpicia: Commentaries, 1475-1990. Oxford : Oxford University Press.

Stevenson, J. 2005. Women Latin Poets: Language, Gender and Authority, from Antiquity to the Eighteenth Century. Oxford : Oxford University Press.

Syme, R. 1981. “A Roman Orator Mislaid.” CQ 31 : 421-427.

Wiseman, T.P. 1974. Cinna the Poet and Other Roman Essays. Leicester : Leicester University Press 


\section{NOTES}

1. For Ovid's portrayal of Thisbe as a skilled erotic communicator, evoking the language of Sulpicia, see Hallett (2009c).

2. See the OLD s.v. "Lesbia" 1018, which cites Propertius 2.32.88, "whose Lesbia is better known than Helen" (Lesbia quis ipsa notior est Helena).

3. Ovid often plays on the two senses of the plural noun amores - "love affairs" and "love poems," the latter of course the title of his own erotic elegies: as he uses the term in this, literary, sense at 360 , immediately before listing the Greek poets who wrote of love with impunity, we may assume he is engaging in word play here as well.

4. For Catullus' expressions of admiration for Sappho, see, for example, Hallett (2006) 66-68, arguing that the phrase Sapphica Musa may refer to Sappho's poetic inspiration, Sappho herself, or Lesbia herself. For Ovid on the Muses, see Sharrock (2002).

5. For evidence suggesting the identification of Catullus' Lesbia with Clodia Metelli, see, for example, Hejduk, 3-9.

6. For Catullus' representations of Lesbia as speaking poetically in these and other poems, see Hallett (2006) 76-85.

7. See Hallett (2006) 76-77, taking issue with Hemelrijk, 175.

8. For this Metella, see Hallett (2006) 77-78; and Wiseman, 188-191.

9. For this Servius, see Hallett (2008) 178 and 185-191; for the view that this man is Sulpicia's grandfather, see Syme (1981).

10. For Messalla, see Pelling, 1580. for his patronage of Ovid, see, for example, EpistulaeEx Ponto 1.7.27 ff. ; 2.2.51, 97 ; 2.3.73ff. For Sulpicia, see also Keith (1997), Skoie (2002) and Stevenson (2005): 36-44.

11. For Tibullus' date of death, see the epigram by Domitius Marsus quoted in the Suetonian Vita Tibulli: Te quoque Vergilio comitem non aequa, Tibulle,/Mors iuvenem campos misit ad Elysios/Ne foret, aut elegis molles qui fleret amores/aut caneret forti regia bella pede, "Tibullus, unfair Death also sent you as a young man, Vergil's companion, to the Elysian fields so that there might not be anyone to weep over delicate loves in elegies, or not sing of kingly wars in powerful verse." For Ovid's quotes from, and rewriting of, Tibullus 1.1 and 1.3 in Amores 3.9, see, for example, Hallett (2009b). 12. For evidence and arguments on the identity of Perilla, see, for example, Hemelrijk, 149-151 and 320-321.

13. For the relationship between the Ars Amatoria, Augustus' moral legislation, and Ovid's exile, see Gibson (2003) 25-37, who regards the error as the main cause of Augustus' displeasure, and the carmen as either a "smokescreen" or "as a form of probabile ex vita", since several years intervene between the publication of the Ars and Ovid's exile.

14. For the dates, and purport, of Augustus' “moral legislation”, see, for example, Keith (1997) 295-296.

15. For Amores 3.14 as alluding to the elegies of Sulpicia, and rebuking her poetic persona, see Hallett (2009a) 141-155.

16. The phrase lux mea is found in earlier Latin erotic poetry-Catullus uses it for his female beloved at 68.132 and 160- but Ovid is here concerned with its use by women.

17. On Sappho's sexual representation, see, for example, various essays in Greene (1996) and especially Gordon (1996).

18. See, for example, Sharrock (1994) ; Knox (1995) :294-295.

19. See Hallett (2005) on Ovid's echoes of earlier Latin poetry, particularly that of Catullus, in Heroides 15. 


\section{ABSTRACTS}

Ovid's discussions of Roman love poetry - as poet-speaker in the Amores and praeceptor amoris in the Ars Amatoria, in propria persona in his exile poems - do not evidently acknowledge the work of any Roman women love poetswhile according prominence to the Greek female poet Sappho. I account for this puzzling feature of his writing by arguing that he makes such acknowledgments in a subtle and indirect way, through allusions, often to speak critically of Roman women's love poetry, and that he diminishes their work in order to identify himself as Sappho's true Roman counterpart.

INDEX

Mots-clés: Ovid, Sappho, Women, Latin love poetry, Catullus, Lesbia, Clodia, Metella, Perilla, Sulpicia

\section{AUTHOR}

JUDITH P. HALLETT

University of Maryland, College Park 